\title{
Use of medicinal herbs by patients with severe asthma managed at a Referral Center
}

\author{
Tacila Pires Mega ${ }^{1}$, Pablo de Moura Santos ${ }^{1,2 *}$, Adelmir Souza-Machado ${ }^{2}$, \\ Lúcia de Araújo Beisl Costa Noblat ${ }^{1}$, Álvaro Augusto Cruz $^{2}$
}

${ }^{1}$ University Hospital Professor Edgar Santos, Federal University of Bahia (HUPES/UFBA), ${ }^{2}$ Program for the Control of Asthma in Bahia (ProAR)

\begin{abstract}
Asthma is a chronic inflammatory disease of the airways that may lead to limitations in regular activities, to hospitalizations and a decrease in quality of life. Adherence to drug treatment is crucial for control of the disease. The use of medicinal herbs can reduce adherence to prescriptions, as the medication may be replaced by infusions or herbal products. The objective of this study was to evaluate the frequency of use of traditional herbal medicine among severe asthmatics in Salvador. Information on use of homemade remedies was obtained through application of a questionnaire during patient visits to a referral center. We also collected data on economic and social aspects as well as disease control. One hundred and forty-four $(91,1 \%)$ out of one hundred and fifty-eight patients evaluated used herbal medicines, but only $26.5 \%$ attributed improvement of asthma symptoms to this alternative treatment and only 8 had substituted a prescribed medication by herbal medicines. There was a trend towards lower adherence to prescription drug treatment in this group of patients. Despite the high frequency of use of medicinal herbs in our sample, there was no improvement in the asthma treatment in this population compared to non-users. Adherence to conventional drug treatment was satisfactory and there was neither reduction in asthma control nor increase in hospitalizations among the users of medicinal plants.
\end{abstract}

Uniterms: Asthma/adherence to drug treatment. Medicinal herbs/use.

\begin{abstract}
A asma é uma enfermidade inflamatória crônica das vias aéreas que pode resultar em limitações nas atividades diárias, internações e prejuízo da qualidade de vida. A adesão ao tratamento medicamentoso é fundamental para o controle da doença. $\mathrm{O}$ uso de plantas medicinais pode reduzir a adesão ao tratamento prescrito, à medida que os medicamentos são substituídos por chás ou ervas. O objetivo deste estudo foi avaliar a frequência de uso de plantas medicinais entre asmáticos graves em Salvador. As informações sobre uso de remédios caseiros foram obtidas por meio de questionário durante a visita dos pacientes a um centro de referência. Foram coletados dados econômicos, sociais e de controle da doença. Cento e quarenta e quatro $(91,1 \%)$ dos cento e cinqüenta e oito pacientes avaliados utilizavam plantas medicinais, dos quais apenas $26,5 \%$ atribuíam melhora dos sintomas da asma a este tratamento alternativo e somente 8 pacientes já haviam feito a substituição de medicamento por alguma planta medicinal. Houve tendência a menor adesão ao tratamento medicamentoso neste grupo de pacientes. Apesar da alta frequência do uso de plantas medicinais na nossa amostra, não houve melhora no tratamento da asma desta população em relação aos não-usuários. A adesão ao tratamento medicamentoso foi satisfatória, não havendo piora no controle da asma ou aumento em hospitalizações entre os usuários de plantas medicinais.
\end{abstract}

Unitermos: Asma/adesão ao tratamento medicamentoso. Plantas medicinais/uso.

\section{INTRODUCTION}

Asthma is a chronic inflammatory syndrome charac-

\footnotetext{
*Correspondence: P. M. Santos. Program for Asthma Control in Bahia - ProAR. Rua Carlos Gomes, 270 - $7^{\circ}$ Andar - 40060-330 - Salvador - BA, Brasil. E-mail: pablomoura25@yahoo.com.br
}

terized by airway hyperresponsiveness and variable airway airflow limitation, characterized by recurrent episodes of wheezing, breathlessness, chest tightness and coughing, particularly at night and awaking in the morning (SBPT, 2006). It is a highly prevalent global disease, affecting approximately 300 million individuals worldwide (WHO, 
2007). Among adults, Brazil has one of the highest prevalence in 70 countries studied, afflicting $12.6 \%$ of women and $11.5 \%$ of men (WHO, 2009). The prevalence of asthma symptoms in Brazil is also high among children (24\%) and adolescents (20\%) (Asher et al., 2006). There is strong evidence that the prevalence of asthmas has increased in a number of countries in recent decades (Yan et al., 2005; Urueña-Carvajal et al., 2005; Solé et al., 2006).

Drug treatment of severe asthma is based on the administration of anti-inflammatory medications (inhaled corticosteroids) for prevention of symptoms and relief medication (bronchodilators $\beta 2$ agonists) during exacerbations (SBPT, 2006; GINA, 2007). Studies have shown the preventive treatment of asthma is cost-effective, especially in more severe and uncontrolled disease (Franco et al., 2007).

An evaluation of factors affecting the treatment of asthma conducted in India revealed that $79 \%$ of patients used alternative therapies such as home remedies, teas, homeopathy and yoga reporting that they perceived symptom relief (Singh, Sinhá, Gupta, 2002). A review on the use of alternative therapies in patients with asthma reported that these practices ranged from $4 \%$ to $79 \%$ in adults and $33 \%$ to $89 \%$ in children, although it failed to find evidence of the effectiveness of these alternative approaches (Szelenyi, Brune, 2002). The high frequency of use of traditional medicine therapies provided the rationale for studying their use in patients with severe asthma at a referral center.

There are many reasons why patients choose herbal treatments such as, the perception that synthetic drugs are expensive, over-prescribed and can be dangerous. Moreover, medicinal plants are usually seen by lay people as "natural" and thus considered safe. Dissatisfaction with treatment and poor communication between doctors and patients were also cited as predictors of non-adherence. The fact that asthma is a chronic disease and therefore requires longer treatment may also be a predictor for those affected to seek alternative therapies, such as the use of medicinal plants (Slader et al., 2006).

In Brazil, especially in the Northeast, the use of home remedies and herbal medicines in treating various diseases is common and culturally widespread. The aim of this study was to evaluate the use of medicinal plants among alternative treatments used by participants on an asthma program and assess its relationship with economic and social factors as well as disease control.

\section{METHODS}

This was a cross-sectional study assessing the prevalence of use of medicinal plants in patients with se- vere asthma. A sample of one hundred and sixty patients treated regularly at a Referral Center for Asthma Control in Bahia (ProAR), located in Salvador city, northeastern Brazil, was evaluated for one year (August 2006 to July 2007). The participants were patients of both sexes, aged over 18 years, with severe persistent asthma, as defined by the criteria established by the IV Brazilian Guidelines on Asthma (SBPT, 2006), who were admitted to ProAR.

The variables were measured at four-monthly visits by means of interview and structured questionnaire. Each interview occurred on the same day that the patients received their medications at the pharmacy and after provision of pharmaceutical care. At interviews, data were collected related to the use of medicinal plants and about the belief in the effectiveness of these alternatives. Patients were also asked if they had ever replaced the medical treatment received at ProAr by medicinal plants. The medicinal plants were cited by patients using their vernacular names and their corresponding scientific names were later matched through a literature survey of native and cultivated medicinal plants in the state of Bahia and other regions of northeast Brazil.(Corrêa, Penna, 1984; Cruz, G.L, 2005; AGRA et al., 2008; Moreira et al., 2002; Pinto, Amoroso, Furlan, 2006).

In addition, information about socioeconomic and demographic characteristics, current control and symptoms of the disease as well as emergency room visits over the study period, was collected. Treatment adherence was measured by counting the capsules or weighing the inhalers used by patients to assess compliance with treatment during the study period. A cut-off point of $80 \%$ of the doses prescribed in the period was used to define patients as adherent or otherwise (Santos et al., 2008).

The socioeconomic and demographic characteristics analyzed included gender, age, educational level, city of residence, religion, occupational status and family income. Severity of the symptoms was based on the Asthma Control Questionnaire (ACQ) (Junniper et al., 1999). The issues on the ACQ comprise nocturnal awakenings, exacerbation of symptoms, activity limitations, dyspnea, wheezing and use of rescue medication (bronchodilator $\beta 2$ agonist). A mean value greater than or equal to 1.5 on the ACQ was defined as uncontrolled asthma.

This study was approved by the Ethics Committee of the Medicine Faculty of Bahia, Federal University of Bahia (UFBA). All patients signed an informed consent form (ICF) and identifying data were kept confidential. Data were analyzed using the Statistical Package for the Social Sciences, version 9.0 (SPSS Inc., Chicago, IL, USA). The mean and standard deviation were calculated 
for the quantitative variables that had a normal distribution. Categorical variables were expressed as frequency and percentage. The Chi-square test was used for evaluating the statistical significance among categorical variables while Student's t-test was used for the comparison among means of quantitative data. The level of statistical significance was set at alpha $<0.05$. The degree of association among the studied variables was evaluated using odds ratios with a confidence interval of $95 \%$.

\section{RESULTS}

One hundred and sixty patients were initially included in this study. However, two patients withdrew consent and decided not to continue participating in the study. The use of medicinal plants was evaluated in 158 individuals who were given full information on the study. Of these, $119(75 \%)$ were female and $39(25 \%)$ were men, with a median age of $49 \pm 14$ years. Sociodemographic data and its relation to the use of medicinal plants are given in Table I. One hundred and forty-four $(91.1 \%)$ patients reported

TABLE I - Sociodemographic characteristics of patients with asthma and relation to use of herbal medicines

\begin{tabular}{lcc}
\hline Attribute & $\mathrm{n}(\%)$ & $\begin{array}{c}\text { herbal medicine } \\
\text { use - } \mathrm{n}(\%)\end{array}$ \\
\hline
\end{tabular}

Gender

Male

$39(24.6 \%)$

$35(89.7 \%)$

Female

$119(75.3 \%)$

$109(91.6 \%)$

Age in years

$49 \pm 13.9$

$50 \pm 13.1$

$\left(\right.$ mean $\left.\pm \mathrm{SD}^{1}\right)$

Religion

$\begin{array}{lcc}\text { Catholic } & 93(58.8 \%) & 86(92.5 \%) \\ \text { Protestant } & 33(20.8 \%) & 31(93.9 \%) \\ \text { Other } & 25(15.8 \%) & 22(88.0 \%) \\ \text { No religion } & 07(4.4 \%) & 05(71.4 \%)\end{array}$

City of residence

$\begin{array}{lcc}\text { Salvador } & 131(82.9 \%) & 123(93.9 \%)^{*} \\ \text { Other cities in } & 27(17.1 \%) & 21(77.7 \%) \\ \text { Bahia State } & & \end{array}$

\begin{tabular}{lcc}
\hline Schooling & $\begin{array}{c}\text { Number of } \\
\text { patients (\%) }\end{array}$ & $\begin{array}{c}\text { Patients using herbal } \\
\text { medicines (\%) }\end{array}$ \\
\hline Illiterate & $15(9.5 \%)$ & $15(100 \%)$ \\
Elementary & $88(55.7 \%)$ & $80(90.9 \%)$ \\
Secondary School & $51(32.3 \%)$ & $46(90.2 \%)$ \\
Higher & $04(2.5 \%)$ & $03(75.0 \%)$ \\
\hline
\end{tabular}

*statistically significant difference $(\mathrm{P}<0.05) \quad{ }^{1} \mathrm{SD}$ - standard deviation the use of "homemade remedies". In all, 79 different types of plants and / or traditional medicinal preparations were cited, considering various ways of preparation or combinations reported by patients (decoction, infusion, syrups, macerated and mixed herbs). The medicinal plants most cited included: Lippia alba, Cymbopogon citratus, Foeniculum vulgare, Matricaria chamomilla and Peumus boldus, as shown in Table II.

TABLE II - Plants or medicinal preparations most used by this subgroup of patients

\begin{tabular}{|c|c|c|c|}
\hline Scientific Name & $\begin{array}{c}\text { Vernacular Name } \\
\text { (Portuguese) }\end{array}$ & $\begin{array}{c}\text { Number of } \\
\text { patients }\end{array}$ & $\%$ \\
\hline Lippia aba Mill & ("erva-cidreira") & 139 & 96.5 \\
\hline Foeniculum vulgare Mill & (“erva-doce”) & 88 & 61.1 \\
\hline $\begin{array}{l}\text { Matricaria } \\
\text { chamomilla } \mathrm{L} .\end{array}$ & (“camomila") & 67 & 46.5 \\
\hline $\begin{array}{l}\text { Cymbopogon } \\
\text { citratus (DC.) Stapf }\end{array}$ & ("capim-santo") & 64 & 44.4 \\
\hline \multirow[t]{2}{*}{ Peumus boldus Molina. } & (“boldo") & 40 & 27.7 \\
\hline & $\begin{array}{c}\text { "Garrafada" } \\
\text { (mixture of } \\
\text { unknown herbs) }\end{array}$ & 12 & 8.3 \\
\hline $\begin{array}{l}\text { Baccharis trimera } \\
\text { Less (DC) }\end{array}$ & (“carqueja") & 10 & 6.9 \\
\hline Mentha spp. & (“menta") & 09 & 6.2 \\
\hline Cordia verbenácea DC & ("maria-preta") & 08 & 5.5 \\
\hline $\begin{array}{l}\text { Cinnamomum } \\
\text { zeylanicum Blume }\end{array}$ & (“canela") & 08 & 5.5 \\
\hline $\begin{array}{l}\text { Zingiber officinalis } \\
\text { Roscoe }\end{array}$ & ("gengibre") & 08 & 5.5 \\
\hline $\begin{array}{l}\text { Schinus terebinthifolius } \\
\text { Raddi }\end{array}$ & ("aroeira") & 07 & 4.8 \\
\hline $\begin{array}{l}\text { Ilex paraguayensis } \\
\text { St. Hill }\end{array}$ & ("erva-mate") & 07 & 4.8 \\
\hline Ananas sativus Schult & (“abacaxi”) & 05 & 3.4 \\
\hline Citrus sp. & ("limão") & 04 & 2.7 \\
\hline Allium sativum $\mathrm{L}$. & ("alho") & 03 & 2 \\
\hline
\end{tabular}

When the patients were asked about their impressions regarding the use of traditional medicine to control asthma symptoms, $42(26.5 \%)$ reported they believed symptoms were improved by these products, while 109 $(69.0 \%)$ perceived no benefit. Only eight (5.1\%) respondents reported having substituted prescription drugs by medicinal plants.

No statistically significant difference was found in use of medicinal plants for gender, religious belief or educational level. There was a more frequent association 
between the use of these medicinal preparations among residents in Salvador than among residents of other parts of the country, where this difference reached statistical significance $(\mathrm{P}=0.006)$.

Socioeconomic data and its relation to the use of medicinal plants are shown in Table III.

TABLE III - Socioeconomic characteristics of patients with severe asthma and their relation to use of traditional medicine

\begin{tabular}{lcc}
\hline Attribute & $\begin{array}{c}\text { Number of } \\
\text { patients (\%) }\end{array}$ & $\begin{array}{c}\text { Use of herbal } \\
\text { medicines (\%) }\end{array}$ \\
\hline Occupational Status & & \\
$\quad$ Employed & $48(30.4 \%)$ & $40(83.3 \%)^{*}$ \\
Unemployed & $31(19.6 \%)$ & $29(93.5 \%)$ \\
Pensioner & $36(22.7 \%)$ & $35(97.2 \%)$ \\
Housewife & $39(24.7 \%)$ & $37(94.8 \%)$ \\
$\quad$ Student & $04(2.5 \%)$ & $03(75.0 \%)$ \\
Family Income & & \\
$\leq 2$ minimum wages & $128(81.0 \%)$ & $117(91.4 \%)$ \\
$>2$ minimum wages & $26(16.5 \%)$ & $23(88.5 \%)$ \\
No information & $04(2.5 \%)$ & --------- \\
\hline
\end{tabular}

*statistically significant difference $(\mathrm{P}<0.05)$

The use of medicinal plants among patients in employment was significantly lower than for other groups $(\mathrm{P}=0.01)$. There was no significant difference regarding family income.

In this sample, $112(70.9 \%)$ patients were considered adherent to the inhaled corticosteroid according to the adopted cutoff point ( $>80 \%$ of doses taken). The overall rate of adherence was $83.9 \%$. Adherence to inhaled corticosteroid of patients using medicinal plants (85\%) was significantly higher than patients who did not use traditional medicine preparations $(72.3 \%)(\mathrm{P}<0.001)$. No difference was found in treatment adherence among patients who believed in controlling symptoms after the use of medicinal preparations than among those who did not believe this $(84.1$ versus $84.6 \%, \mathrm{P}=0.8)$. However, patients who reported having stopped using the drugs prescribed in favor of medicinal plants had lower adherence than patients who had never substituted the conventional drugs $(76.8 \%$ vs. $85.3 \%$, respectively $(\mathrm{P}=0.057)$.

Fifty-one (32\%) patients reported having visited the emergency room during the study period, thus averaging $3.2 \pm 2.6$ visits (mean \pm SD). No statistical difference in asthma control was found between patients using medicinal plants and those who did not, and no difference in the number of emergency room visits was registered during the period. Regarding the daily use of inhaled corticoste- roids, 142 patients using medicinal plants had an average dose of $885 \mathrm{mcg} /$ day of budesonide or beclomethasone, while those $(\mathrm{n}=15)$ who reported not using medicinal plants had an average of $740 \mathrm{mcg}(\mathrm{P}=0.021)$.

No statistically significant difference was observed in the use of medicinal plants among patients newly admitted to the ProAR compared with others who had been followed for longer than six months.

\section{DISCUSSION}

Asthma is one of the most common chronic diseases worldwide (WHO, 2007). It is known that there is a particularly high frequency of use of herbal plants and traditional medicine among low-income populations, such as the patients seen at the ProAR. Even among adults with free access to specific treatment for asthma, the use of drugs and other non-prescribed products is common practice. A study by Blanc et al. (1997) showed an association of this practice to an increased risk of adverse reactions and treatment failure.

In the present study, the authors observed a high consumption of medicinal plants. These patients receive their medications free through the Ministry of Health of Brazil and the Department of Health of the State of Bahia and are assisted by a multidisciplinary team comprising doctors, nurses, pharmacists, social workers and psychologists.

Studies aimed at determining the use of alternative therapies in patients with asthma are not uncommon. Alternative therapies employed include medicinal plants and the use of other practices such as acupuncture, aromatherapy, Chinese herbs, animal products, homeopathy and relaxation techniques ( $\mathrm{Ng}$ et al., 2003; Blanc et al., 2001, Ernst, 1998; Partridge, Dockrell, Smith, 2002). Methodological differences, both geographical and conceptual, among the various studies make any useful comparison difficult. A review conducted in 2002 compiling 17 publications that evaluated the use of alternative therapies in patients with asthma also pointed to the inconsistency and poor quality of the studies as a constraint precluding valid comparisons (Slader, 2006).

Factors such as gender, religion, educational level and economic status (monthly income) did not affect the use of medicinal plants in this subgroup of patients. These findings contrast with those described by Shaw et al. (2008), who showed an association of higher educational level and gender (female) with a greater use of medicinal plants in a study conducted in England. By contrast, Clement et al. (2005) found no association of use of herbal drugs with gender, age, place of residence or occupational status in a study conducted among patients with asthma in Trinidad and Tobago. 
The severity of asthma is also relevant for interpreting results. Patients with severe clinical symptoms and in use of high doses of corticosteroids, tend to adhere more to the treatment prescribed and not replace it by herbal medicines. In the study conducted in Trinidad and Tobago with 191 patients assessing the predictors for use of medicinal plants showed that patients with moderate or severe asthma did not believe that the use of medicinal plants alone was sufficient to relieve the symptoms (Clement et al. 2005). Most of those interviewed stated that the medicines prescribed had a greater effect than the medicinal plants in controlling symptoms. In our sample, patients using medicinal plants had a greater average dose of corticosteroids than non-users. This result suggests that individuals with poorer asthma control use additional therapies not prescribed by the doctor in an attempt to supplement their treatment.

In this study of 144 patients who claimed to use homemade teas or herbal medicines, 42 (26.5\%) believed that these products contributed to relief of symptoms. Examining the supposed pharmacological properties of the plants most cited by the patients, reveals that the majority are used as antispasmodics, tranquilizers or antiinflammatory drugs (Abuhamdah et al. 2008; Tirapelli et al., 2007; McKay, Blumberg, 2006). These properties could contribute to the control of asthma symptoms, but should not be indicated for treatment of this disease due lack of evidence of their efficacy and safety. Other "natural remedies" were cited such as mint, mate, ginger, pineapple, garlic and "garrafada" bottle (mixed herbs). These are popularly referred for asthma and "breathing problems" and are cited in some secondary sources that discuss medicinal plants (Almeida, 2003; Lainetti, Brito, 1979), as well as informal sources of broad and easy access available on the Internet (ESALQ, 2008; ABMC, 2007). All products mentioned are widely sold in street markets and other outlets of urban centers in Brazil. In our study, patients were not questioned as to whether they informed their doctors about the use of medicinal plants nor if the orientation of doctors influenced the patient's decision regarding the use of these products.

When patients abandon conventional treatments for alternative medicines they are at risk of exacerbation and chronic complications due to inadequate control of disease, adverse effects and drug interactions (Barnes, 2003). The high risk of complications and exacerbations can result in a higher number of emergency service visits and deaths (Jose et al., 2007). In our sample, emergency admissions were no higher in patients who used medicinal plants. Adherence to treatment observed in our study sample was similar among users and nonusers of alternative traditional medicine, which may have been the result of interventions in health education and regular guidance given to patients of this referral center. This factor limits the external validity of this study because the educational program is directly related with treatment adherence in this sample of users of traditional medicine. However, asthma patients do not always receive the benefit of a multidisciplinary education program. Ensuring access to medicines and regular monitoring with a professional healthcare team suggest that these patients are more informed about the effects of other therapies, replacement of medication or treatment dropout. In this study, although $91.1 \%$ of patients interviewed stated they used tea or various natural medicinal preparations, only $8(5.1 \%)$ confirmed having replaced conventional treatment with alternative therapy.

Despite the high frequency of herbal medicine use by patients with severe asthma in ProAR, adherence to drug treatment was good. The use of traditional medicine in this sample was not associated with poorer control of the disease or an increase in the number of admissions. However, it is important to discuss with patients about potential adverse effects from active substances from medicinal plants associated to the chronic use of medicines which have not yet been studied. The popular saying "If it is natural, it is safe" can lead common people to self-medication and treatment compromise. Health professionals should remain alert for early identification of the possible replacement of prescribed medical treatment by herbal therapies, especially in severe asthma, in order to ensure maximum effectiveness of the treatment and control of disease in these individuals. In conclusion, the patients with severe asthma in our study have used medicinal plants concomitantly with drug therapy, but the use of plants cited in this study did not provide better asthma control nor was associated with lower adherence to prescribed treatment or to unfavorable clinical outcomes. However, in a reference clinic for severe asthma where patients participate in education programs and receive drugs free of charge, the use of alternative treatments was not associated with lower adherence to prescribed treatment or to unfavorable clinical outcomes.

\section{REFERENCES}

ABUHAMDAH, S.; HUANG, L.; ELLIOT, M. S.; HOWES, M. J.; BALLARD, C.; HOLMES, C.; BURNS, A.; PERRY, E. K.; FRANCIS, P. T.; LEES, G.; CHAZOT, P. L. Pharmacological profile of an essential oil derived from Melissa officinalis with anti-agitation properties: focus on ligand-gated channels. J. Pharm. Pharmacol., v.60, n.3, p.377-384, 2008. 
AGRA, M. F.; SILVA, K. N.; BASÍLIO, I. O. J. D.; FREITAS, P. F.; BARBOSA-FILHO, J. M. Survey of medicinal plants used in the region Northeast of Brazil. Braz J. Pharmacogn., v.18, n.3, 2008.

ALMEIDA, M. Z. Plantas medicinais. 2.ed. Salvador: EDUFBA, 2003. 214 p.

ASHER, M. I.; MONTEFORT, S.; BJÖRKSTÉN, B.; LAI, C. K.; STRACHAN, D. P.; WEILAND, S. K.; WILLIAMS, H. ISAAC Phase Three Study Group. Worldwide time trends in the prevalence of symptoms of asthma, allergic rhinoconjunctivitis, and eczema in childhood: ISAAC Phases One and Three repeat multicountry cross-sectional surveys. Lancet, v.368, n.9537, p.733-743, 2006.

\section{A S S OCIAÇÃO BRASILEIRA DE MEDICINA} COMPLEMENTAR. ABMC. Biblioteca de fitoterapia. Available at: <http://www.medicinacomplementar.com.br/ bibfitoterapia.asp>. Accessed on: 16 may. 2008.

BARNES, J. Quality, efficacy and safety of complementary medicines: Fashins, facts and future: Part II: efficacy and safety. Br. J. Clin. Pharmacol., v.55, n.4, p.331-340, 2003.

BLANC, P. D.; KUSCHNER, W. G.; KATZ, P. P.; SMITH, S.; YELIN, E. H. Use of herbal products, coffee or black tea, and over-the-counter medications as self-treatments among adults with asthma. J. Allergy Clin. Immunol., v.100, n.6, p.789-791, 1997.

BLANC, P. D.; TRUPIN, L.; EARNEST, G.; KATZ, P. P.; YELIN, E. H.; EISNER, M. D. Alternatives teraphies among adults with reported diagnosis of asthma or rhinosinusitis: data from a population-based survey. Chest, v.120, n.5, p.1461-1467, 2001.

CARVAJAL-URUENA, I.; GARCIA-MARCOS, L.; BUSQUETS-MONGE, R.; SUÁREZ-VARELAS, M. M.; ANDOIN, N. G.; BATLLES-GARRIDO, J.; BLANCOQUIRÓS, A.; LÓPEZ-SILVARREY, A.; GARCÍAHERNÁNDEZ, G.; GUILLÉN-GRIMAJ, F.; GONZÁLEZDÍAZ, C.; BELLIDO-BLASCO, J. Geographic variation in the prevalence of asthma symptoms in Spanish children and adolescents: International Study of Asthma and Allergies in Childhood (ISAAC) Phase 3, Spain. Arch. Bronconeumol., v.41, n.12, p.659-666, 2005.
CLEMENT, Y. N.; WILLIAMS, A. F.; ARANDA, D.; CHASE, R.; WATSON, N.; MOHAMMED, R.; STUBBS, O.; WILLIAMSON, D. Medicinal herb use among asthmatic patients attending a specialty care facility in Trinidad. BMC Complement. Altern. Med., v.5, n.3, p.12-18, 2005.

CORRÊA, M. P.; PENNA, L.A. INSTITUTO BRASILEIRO DE DESENVOLVIMENTO FLORESTAL. Dicionário das plantas úteis do Brasil e das exóticas cultivadas. Brasília: Ministério da Agricultura, Instituto Brasileiro de Desenvolvimento Florestal, 1984. 6 v

CRUZ, G. L. Dicionário das plantas úteis do Brasil. 5.ed. Rio de Janeiro: Bertrand Brasil, 1995. 599 p.

ERNST, E. Complementary therapies for asthma: what patients use. J. Asthma, v.35, n.8, p.667-671, 1998.

ESCOLA SUPERIOR DE AGRICULTURA LUÍS DE QUEIROZ (ESALQ). Plantas Medicinais. Available at: $<$ http://ci-67.ciagri.usp.br/pm.> Accessed on: 01 dez. 2008.

FRANCO, R.; SANTOS, A.; NASCIMENTO, H. F.; PONTE, E.; SOUZA-MACHADO, A.; SOUZA-MACHADO, C.; LOUREIRO, S.; BARRETO, M. L.; RODRIGUES, L. C.; CRUZ, A. A. Cost-effectiveness analysis of a state funded program for control of severe asthma. BMC Public Health (online), v.7, n.82, 2007.

GLOBAL INITIATIVE FOR ASTHMA - GINA [homepage on the Internet]. Bethesda: National Heart, Lung and Blood Institute. National Institutes of Health, US Department of Health and Human Services. [cited 2007 Aug 9]. Global Strategy for Asthma Management and Prevention, Global Initiative for Asthma (GINA) 2006. Available at: $<$ http:// www.ginasthma.com>. Accessed on: 18 apr. 2008.

JOSE, V. M.; BHALLA, A.; SHARMA, N.; HOTA, D.; SIVAPRASAD, S.; PANDHI, P. Study of association between use of complementary and alternative medicine and non-compliance with modern medicine in patients presenting to the emergency department. J. Postgrad. Med., v.53, n.2, p.96-101, 2007.

JUNIPER, E. F.; O’BYRNE, P. M.; GUYATT, G. H.; FERRIE, P. J.; KING, D. R. Development and validation of a questionnaire to measure asthma control. Eur. Respir. J., v.14, n.4, p.902-907, 1999. 
LAINETTI, R.; BRITO, N. R. S. A cura pelas ervas e plantas medicinais brasileiras. Rio de Janeiro: Tecnoprint, 1979. $169 \mathrm{p}$.

LEITE, M.; PONTE, E. V.; PETRONI, J.; D’OLIVEIRA JÚNIOR, A.; PIZZICHINI, E.; CRUZ, A. A. Evaluation of the asthma control questionnaire validated for use in Brazil. J. Bras. Pneumol., v.34, n.10, p.756-763, 2008.

MCKAY, D. L.; BLUMBERG, J. B. A review of the bioactivity and potential health benefits of chamomile tea (Matricaria recutita L.). Phytother. Res., v.20, n.7, p.519-530, 2006.

MOREIRA, R. C. T.; COSTA, L. C. B.; COSTA, R. C. S.; ROCHA, E. A. Abordagem etnobotância acerca do uso de plantas medicinais na Vila Cachoeira, Ihéus, Bahia, Brasil. Acta Farm. Bonaerense, v.21, n.3, p.205-211, 2002.

NG, T. P.; WONG, M. L.; HONG, C. Y.; KOH, K. T. C.; GOH, L. G. The use of complementary and alternative medicine by asthma patients. QJM, v.96, n.10, p.747-754, 2003.

PARTRIDGE, M. R.; DOCKRELL, M.; SMITH, N. M. The use of complementary medicine by those with asthma. Respir. Med., v.97, n.4, p.436-438, 2003.

PINTO, E. P. P.; AMOROSO, M. C. M.; FURLAN, A. Conhecimento popular sobre plantas medicinais em comunidades rurais de mata atlântica- Itacaré, BA, Brasil. Acta Bot. Bras., v.20, n.4, p.751-762, 2006.

SANTOS, P. M.; D'OLIVEIRA JÚNIOR, A.; NOBLAT L. A.; MACHADO, A. S.; NOBLAT, A. C.; CRUZ, A. A. Predictors of adherence to treatment in patients with severe asthma treated at a referral center in Bahia, Brazil. J. Bras. Pneumol., v.12, n.34, p.995-1002, 2008.

SHAW, A.; NOBLE, A.; SALISBURY, C.; SHARP, D.; THOMPSOM, E.; PETERS, T. J. Predictors of complementary therapy use among asthma patients: results of a primary care survey. Health Soc. Care Community., v.16, n.2, p.155-164, 2008.

SINGH, V.; SINHA, H. V.; GUPTA, R. Barriers in the management of asthma and attitudes towards complementary medicine. Respir. Med., v.96, n.10, p.835-840, 2002.
SLADER, C. A. Complementary and alternative medicine use in asthma: Who is using what? Respirology, v.11, n.4, p.373-387, 2006.

SOCIEDADE BRASILEIRA DE PNEUMOLOGIA E TISIOLOGIA (SBPT). IV Diretrizes Brasileiras para o manejo da Asma. J. Bras. Pneumol., v.32, n.7, p.S447-S474, 2006.

SOLÉ, D.; WANDALSEN, G. F.; CAMELO-NUNES, I. C.; NASPITZ, C. K. Prevalence of symptoms of asthma, rhinitis, and atopic eczema among Brazilian children and adolescents identified by the International Study of Asthma and Allergies in Childhood (ISAAC)- Phase 3. J. Pediatr., v.82, n.5, p.341-346, 2006.

SZELENYI, I.; BRUNE, K. Herbal remedies for asthma treatment: between myth and reality. Drugs Today, v.38, n.4, p.265-303, 2002.

TIRAPELLI, C. R.; ANDRADE, C. R.; CASSANO, A.O.; SOUZA, F. A.; AMBRosio, S. R.; COSTA, F. B.; OLIVEIRA, A. M. Antispasmodic and relaxant effects of the hidroalcoholic extract of Pimpinella anisum (Apiaceae) on rat anococcygeus smooth muscle. J. Ethnopharmarcol., v.110, n.1, p.23-29, 2007.

WORLD HEALTH ORGANIZATION. World Health Survey. Available at: <http://www.who.int/healthinfo/survey/en >. Accessed on: 13 set. 2009.

WORLD HEALTH ORGANIZATION. Global surveillance, prevention and control of chronic respiratory diseases: a comprehensive approach. Genebra, 2007. Available at: $<$ http:// www.who.int/entity/gard/publications/GARD_ Portuguese.pdf $>$. Accessed on: 10 mar. 2008.

YAN, D. C.; OU L. S.; TSAI, T. L.; WU, W. F, HUANG, J. L. Prevalence and severity of symptoms of asthma, rhinitis, and eczema in 13- to 14-year-old children in Taipei, Taiwan. Ann. Allergy, Asthma Immun., v.95, n.6, p.579-585, 2005.

Received for publication on $6^{\text {th }}$ July 2010 Accepted for publication on $30^{\text {th }}$ March 2011 
